\title{
PENGGUNAAN TEKNOLOGI INFORMASI DAN KOMUNIKASI DALAM SISTEM MANAJEMEN PEMBELAJARAN PADA MASA PANDEMI COVID 19
}

\author{
Adisel $^{1}$, Ahmad Gawdy Prananosa ${ }^{2}$ \\ IAIN Bengkulu ${ }^{1}$, STKIP PGRI Lubuklinggau ${ }^{2}$ \\ $\underline{\text { adisel@gmail.com }}{ }^{1}$
}

\begin{abstract}
ABSTRAK
Tujuan penelitian ini adalah untuk menelaah penggunaan teknologi informasi dalam sistem manajemen di perguruan tinggi di Indonesia yang masih belum termanfaatkan secara maksimal dan merata baik perangkatnya maupun manajemennya. Penelitian ini merupakan kajian jurnal internasional. Hasil penelitian sumber daya input meliputi visualizer/document camera, komputer, papan tulis, student response system, dan program aplikasi. Sumber daya output meliputi proyektor, papan tulis interaktif, dan tampilan : monitor, televisi dan lainnya. Terakhir peralatan ICT lainnya meliputi kamera digital, switcher, perekam digital, dan inovasi lainnya. Simpulan, belum meratanya infrastruktur yang mendukung penerapan teknologi ini dibidang pendidikan dan ketidaksiapan sumber daya manusia untuk memanfaatkan teknologi informasi dan komunikasi dalam proses pembelajaran.
\end{abstract}

Kata Kunci:Teknologi Informasi, Komunikasi, Manajemen Pembelajaran

\begin{abstract}
The purpose of this study is to examine the use of information technology in management systems in tertiary institutions in Indonesia which are still not maximally and evenly utilized both in terms of equipment and management. This research is an international journal study. The results of input resource research include visualizer / document camera, computer, whiteboard, student response system, and application program. Output resources include projectors, interactive whiteboards, and displays: monitors, televisions and more. Finally, other ICT equipment includes digital cameras, switchers, digital recorders, and other innovations. Conclusions, the uneven infrastructure that supports the application of this technology in the field of education and the unpreparedness of human resources to utilize information and communication technology in the learning process.
\end{abstract}

Keywords: Information Technology, Communication, Learning Management

\section{PENDAHULUAN}

Dalam kondisi dunia dan juga Indonesia sedang menghadapi pandemi Virus Corona 19 ini mengharuskan dunia pendidikan bertransformasi untuk mengikuti perubahan karena sistem pembelajaran yang digunakan selama ini adalah bertatap muka di kelas menjadi sistem daring (dalam jaringan) dengan memanfaatkan teknologi internet. Sistem informasi sebagai suatu sistem yang merupakan 
kumpulan elemen-elemen yang saling berinteraksi untuk mencapai tujuan tertentu, mempunyai beberapa komponen yang saling terkait dan membentuk jalinan kerja yang kompak untuk mencapai sasaran (Adisel, 2019). Oleh karena itu era globalisasi saat ini, perkembangan teknologi informasi dan komunikasi yang semakin pesat dan telah merambah berbagai aspek kehidupan manusia, termasuk dalam dunia pendidikan di berbagai negara termasuk Indonesia. Bahkan adanya tekanan teknologi informasi dan komunikasi atau Information and Communication Technologies (ICT) yang sangat besar terhadap sistem pendidikan secara global karena teknologi yang berkembang menyediakan kesempatan yang sangat besar untuk mengembangkan manajemen pendidikan dan proses pembelajaran di perguruan tinggi (Wiliam, 2015).

ICT adalah sistem pembelajaran berbasis multimedia (teknologi yang melibatkan teks, gambar, suara, dan video) mampu membuat penyajian suatu topik bahasan menjadi menarik, tidak monoton dan mudah untuk dicerna. Peran yang sangat penting dan strategis ini sebagai pusat belajar, pusat budaya, dan pusat peradaban menuntut lembaga-lembaga pendidikan untuk dapat mengembangkan aktivitas pembelajaran yang jelas dan daya jangkau yang luas. Namun tetap diingat bahwa ICT hanyalah sebagai alat bantu dalam proses pembelajaran. Menurut UNESCO (2011), ada lima manfaat yang dapat diraih melalui penerapan ICT dalam sistem pendidikan, yaitu: 1) mempermudah dan memperluas akses terhadap pendidikan, 2) meningkatkan kesetaraan pendidikan, 3) meningkatkan mutu pembelajaran, 4) meningkatkan profesionalisme guru dan 5) meningkatkan efektifitas dan efisiensi manajemen, tata kelola, dan administrasi pendidikan.

Mengetahui dan manyadari besarnya manfaat ICT bagi dunia pendidikan, para ahli UNESCO menganjurkan agar semua negara; khususnya negara berkembang; meningkatkan berbagai sumber daya yang diperlukan untuk mengelaborasi ICT dalam berbagai kebijakan, strategi, dan aktivitas pendidikan. Sekarang ini sebagian besar negara menekankan pembelajaran dan menerapkan teknologi informasi dan komunikasi sebagai inti dari sistem pendidikan mereka (Hasemy et al., 2012). Di Indonesia, berdasarkan Rencana Pembangunan Jangka Menengah Nasional (RPJM) 2020-2024 ditegaskan pada Perioritas Kemendikbud yang keempat adalah pengembangan teknologi. Fokus dari teknologi ini menurut Menteri adalah untuk membantu semua manusia dalam sestem untuk melaksanakan tugasnya dengan cara yang lebih baik. Kementerian Pendidikan dan Kebudayaan, untuk dapat memberikan pelayanan prima, salah satu yang perlu dilakukan adalah pengembangan teknologi informasi dan komunikasi (ICT) yang dilakukan melalui pendayagunaan ICT di bidang pendidikan yang mencakup peran ICT sebagai substansi pendidikan, alat bantu pembelajaran, fasilitas pendidikan, standar kompetensi, penunjang administrasi pendidikan, alat bantu manajemen satuan pendidikan, dan infrastruktur pendidikan.

Berkaitan dengan hal di atas, fenomena pemanfaatan ICT dalam pembelajaran di lembaga pendidikan semakin bergaung, bahkan dalam kurikulum 2013 ICT memegang peranan yang sangat penting dalam pelaksanaan pembelajaran. Pada kurikulum 2013 dijelaskan bahwa pembelajaran menerapkan prinsip siapa saja adalah guru, siapa saja adalah siswa, dan dimana saja adalah kelas. Oleh karena itu, pemanfaatan ICT diperlukan dalam rangka efektivitas dan efisiensi pembelajaran. 
ICT dalam pembelajaran dapat menjadi dua peran, yaitu : (1) sebagai media presentasi pembelajaran, misalnya berbentuk slide power point dan animasi dengan program flash; (2) sebagai media pembelajaran mandiri atau e-learning, misal peserta didik diberi tugas untuk membaca atau mencari sumber dari internet, mengirimkan jawaban tugas, bahkan mencoba dan melakukan materi pembelajaran. Melalui e-learning, belajar tidak lagi dibatasi oleh ruang dan waktu. Belajar dapat dilakukan kapan saja dan dimana saja. Hal ini mendorong peserta didik untuk melakukan analisis dan sintesis pengetahuan, menggali, mengolah dan memanfaatkan informasi, menghasilkan tulisan, informasi, dan pengetahuan sendiri. Agar peserta didik terbantu mengembangkan dan menyusun pengetahuan sendiri, tanpa langsung bimbingan guru, maka situasi belajar yang disediakan baginya haruslah konstruktivistik (Prawiradilaga, 2014). Peranan media digital dapat dimaksimalkan pemberdayaannya melalui desain pembelajaran, teori belajar, dan desain pesan sehingga dapat menghasilkan pengalaman belajar yang baik bagi peserta didik.

Namun pada kenyataannya, penerapan ICT dalam bidang pendidikan di Indonesia masih dalam tahap awal serta masih belum termanfaatkan secara maksimal dan merata. Kendala tersebut disebabkan antara lain oleh belum meratanya infrastruktur yang mendukung penerapan ICT di bidang pendidikan dan ketidaksiapan sumber daya manusia untuk memanfaatkan ICT dalam proses pembelajaran dengan kondisi pandemic covid 19 ini mau tidak mau pendidik ataupun guru harus merubah cara dan system pembelajaran yang biasanya tatap muka beralih ke sistem daring.

\section{METODE PENELITIAN}

Penulisan artikel ini didasarkan kajian dari jurnal internasional yaitu The effectiveness of m-learning in the form of podcast revision lectures in higher education yang ditulis oleh Chris Evans, Student perception on a student response system formed by combining mobile phone and a polling website yang ditulis oleh Adam Wong, An analysis of the use of cloud computing among university lecturers: a case study in Zimbabwe oleh Samuel Musungwini, Beauty Mugoniwa, Samuel Simbarashe Furusa, and Taurai George Rebanowako, Assessing the available ICT infrastructure for collaborative web technologies in a blended learning environment in Tanzania: A mixed methods research yang ditulis oleh John Marco Pima, Michael Odetayo and Rahat Iqbal dan Eliamani Sedoyeka, An e-Curriculum Based Systematic Resource Integration Approach to Web-Based Education oleh William W. Song, Anders Forsman, and Jia Yan, dan A Survey of the Application of Information Communication Technology in Education yang disusun oleh Seyed Ahmad Hashemy, Daryoosh Hayati, and Zainab Hashemy.

Beberapa artikel tersebut menjadi informasi awal bagi penulis tentang berbagai hal yang berkaitan dengan penggunaan teknologi ICT yang dapat menunjang proses pembelajaran apalagi disaat pandemic covid 19 ini. Penerapan media elektronik dalam sistem pembelajaran yang sudah banyak digunakan di negara lain, menjadi bahan pemikiran bagi penulis untuk menuliskan ide dalam artikel ini apalagi dengan suasan pandemi Covid 19 ini, sehingga ICT diharapkan diterapkan dan dikembangkan di Indonesia secara merata sehingga masyarakat 
khususnya pendidik dan peserta didik dapat memperoleh layanan pendiidkan yang perima.

\section{HASIL PENELITIAN}

ICT adalah payung besar terminologi yang mencakup seluruh peralatan teknis untuk memproses dan menyampaikan informasi. Alat pendidikan ICT dapat dibagi menjadi tiga kategori yaitu sumber daya input, sumber daya output, dan peralatan ICT lainnya. Sumber daya input meliputi visualizer/document camera, komputer, papan tulis, student response system, dan program aplikasi. Sumber daya output meliputi proyektor, papan tulis interaktif, dan tampilan : monitor, televisi dan lainnya. Terakhir peralatan ICT lainnya meliputi kamera digital, switcher, perekam digital, dan inovasi lainnya.

Penerapan ICT pada bidang pendidikan telah memberikan kontribusi bagi perkembangan teknologi pembelajaran. Penelitian di dunia telah menunjukan bahwa ICT dapat memimpin dalam perbaikan metode belajar para pelajar serta menghasilkan metode pengajaran yang lebih baik. Sebuah laporan yang ditulis oleh National Institute of Multimedia Education di Jepang membuktikan bahwa peningkatan daya serap para pelajar dengan menggunakan teknologi ICT melalui integrasi kurikulum secara signifikan menghasilkan dampak yang positif, terutama dalam bidang pengetahuan, pemahaman, dan keterampilan praktis.

Dalam proses belajar mengajar konvensional, guru memiliki keterbatasan dalam mengajar siswa, walaupun masih banyak hal-hal positif juga yang dapat diperoleh darinya. Beberapa keterbatasan itu, diantaranya interaksi yang terbatas karena umumnya kelas diisi banyak siswa. Selama ini proses belajar mengajar terkendala karena jumlah siswa yang mengikuti kelas mencapai puluhan. Hal ini menjadikan proses belajar mengajar tidak optimal, karena data dan informasi yang tersampaikan kepada siswa tidak maksimal. Dalam hal ini, beberapa kasus patut diperhatikan. adalah adanya beberapa siswa yang "lambat" dalam memahami materi. "Disinilah komputer memahami anak-anak yang lambat dalam belajar, karena gaya belajar hanyalah permasalahan teknis". Dengan menambahkan infrastruktur berupa personal computer (PC)/komputer, siswa akan mampu mengaktifkan semua indera dan sensitifitasnya melalui melihat, mendengar, dan membaca.

Pemanfaatan ICT sebagai media belajar dan mengajar diperlukan untuk mewujudkan efektifitas dan optimasi pembelajaran, namun perlu disadari bahwa apapun media yang digunakan prinsip pembelajaran tetap dipegang teguh. Pada saat berbicara mengenai "e-Learning" atau pendayagunaan media elektronik untuk efektifitas, efisiensi dan kemenarikan pembelajaran hanya berfokus pada kata " $e$ " dan melupakan "learning"nya itu sendiri. Banyak sekolah yang berlomba-lomba melengkapi sekolahnya dengan fasilitas ICT, tapi pemanfaatannya tidak sesuai dengan kebutuhan. Atau banyak media elektronik yang bisa dimanfaatkan untuk pembelajaran tapi belum dioptimalkan. Keberadaan LCD Projector dan satu laptop dalam satu kelas tidak akan membawa perubahan yang berarti jika hanya digunakan oleh guru untuk menjelaskan pelajaran. Tapi akan jauh membawa perubahan yang berarti jika siswa diberi kesempatan untuk memanfaatkan teknologi tersebut untuk mengungkapkan ide dan pengetahuannya kepada teman-temannya yang lain Ketika teknologi tersebut hanya dimanfaatkan oleh guru untuk mengajar, maka siswa hanya akan memperoleh pengetahuan 
tentang apa yang diajarkan dan sedikit gambar atau ilustrasi yang lebih menarik dan konkrit, itupun jika slide presentasi yang dibuatnya baik. Tapi, ketika dimanfaatkan siswa untuk mempresentasikan ide dan pengetahuannya kepada kawan-kawannya yang lain, maka siswa lain akan memperoleh pengetahuan, dan siswa yang berkesempatan menggunakan teknologi tersebut secara tidak langsung mengasah atau meningkatkan ICT literacy mereka dan kemampuan berpikir kritis, problem solving dan lainnya.

Podcasting melibatkan men-download serangkaian siaran audio atau video (file) ke sebuah media player digital, melalui komputer, selama periode seminggu. Rekaman ini kemudian dapat dinonton atau didengarkan kapan, di mana dan sesering yang siswa inginkan. Podcast merupakan salah satu jenis ICT yang dapat digunakan.

Metode dari Thailand tersebut dapat kita generalisasi untuk memberikan solusi bagi kesenjangan pendidikan yang dirasakan oleh masyarakat Indonesia yang tinggal di daerah pelosok (tertinggal). Solusi yang mungkin dapat dipertimbangkan oleh pemerintah dalam mengatasi hal tersebut diantaranya adalah: (1) Duta daerah tertinggal - Program untuk mengundang duta daerah tertinggal yang terdiri dari perwakilan guru, dosen, siswa maupun mahasiswa dari daerah tersebut untuk mengikuti paket pelatihan pengenalan dan pemanfaatan ICT untuk daerahnya. Bagi mereka yang menjadi duta daerah diberi persyaratan untuk menggali kelemahan daerahnya khususnya bidang pendidikan dan setelah menempuh paket pelatihan mereka diharapkan mampu menjawab solusi untuk daerahnya terkait dengan pemanfaatan ICT. Dengan adanya duta daerah tertinggal tersebut diharapkan mampu menularkan pengetahuan tentang ICT kepada masyarakat di daerahnya. (2) Simple Link- Setelah mengetahui daerah-daerah yang masih belum menerapkan ICT, maka diharapkan pemerintah membuatkan simple link dalam setiap instansi pendidikan untuk akses informasi bagi masyarakan daerah tersebut. (3) Optimalisasi potensi ICT daerah tertinggalPemberdayaan duta daerah tertinggal untuk memberikan ilmunya kepada masyarakat dengan reward berupa fasilitas ICT (duta daerah diberi fasilitas laptop atau garansi internet gratis). Kegiatan ini dapat direalisasikan dalam bentuk pelatihan pemanfaatan ICT. Dengan mengundang duta daerah tertinggal yang dilatih paket penerapan ICT untuk kemudian mereka diberi kewajiban untuk mentransfer ilmu tersebut di daerah mereka. Diharapkan dapat menjadi solusi bagi pemerataan kualitas pendidikan di Indonesia.

Penguasaan ICT kini menjadi bagian dari tuntutan kompetensi guru, baik guna mendukung pelaksanaan tugasnya (penyusunan perencanaan, penyajian pembelajaran, evaluasi dan analisis hasil evaluasi) maupun sebagai sarana untuk mencari dan mengunduh sumber-sumber belajar. Sehingga setiap guru pada semua jenjang harus siap untuk terus belajar ICT guna pemenuhan tuntutan kompetensi tersebut. Pada Peraturan Pemerintah (PP) Nomor 74 Tahun 2008 tentang Guru, menyatakan bahwa "Kompetensi guru meliputi kompetensi pedagogik, kompetensi kepribadian, kompetensi sosial, dan kompetensi profesional yang diperoleh melalui pendidikan profesi”. Aspek-aspek kompetensi yang harus dimiliki (dipenuhi) guru, yang berkaitan dengan ICT adalah pada kompetensi pedagogik : "pemanfaatan teknologi pembelajaran", dan pada kompetensi sosial : "menggunakan teknologi komunikasi dan informasi secara fungsional". Dengan demikian, penguasaan (pemanfaatan) ICT oleh guru dalam 
pembelajaran sangat penting. Tetapi tidak semua guru dapat menguasai dan memanfaatkannya. Oleh karena itu, kemajuan tersebut harus diikuti dengan pengembangan sumber daya tenaga pendidik. Untuk menunjang pengembangan tersebut, dibutuhkan adanya fasilitas ICT.

Di era informasi kini, sudah tidak zaman lagi para tenaga didik gagap terhadap teknologi. Teknologi diharapkan menjadi kesatuan dalam pembelajaran sehingga tercipta peserta didik yang lebih aktif dan mandiri. Guru/dosen juga perlu memiliki kompetensi profesional yaitu selalu meningkatkan dan mengembangkan kualifikasi akademik dan kompetensi secara berkelanjutan sejalan dengan perkembangan ilmu pengetahuan, teknologi dan seni. Pendidik perlu meningkatkan kompetensinya melalui aktivitas kolaboratif dengan kolega, menjalin kerjasama dengan orang tua, memberdayakan sumber-sumber yang terdapat di masyarakat, melakukan penelitian. Guru/Dosen perlu menguasai pemanfaatan ICT untuk kebutuhan belajarnya. Kegiatan belajar dan pembelajaran perlu dikelola dengan baik.

Perlunya tenaga pendidik dalam hal ini dosen dilatih ICT karena : ICT dapat digunakan untuk membantu pekerjaan administratif (Word processor \& Kebutuhan Wajib Tingkat Dasar, Spreadsheet). ICT dapat digunakan untuk membantu mengemas bahan ajar (Multimedia) Kebutuhan pembelajaran. ICT dapat digunakan untuk membantu proses manajemen pembelajaran (E-learning, kebutuhan tingkat lanjut). ICT dapat digunakan untuk dukungan teknis dan meningkatkan pengetahuan agar dapat mewujudkan self running creation (antivirus, tools, jaringan, internet).

Agar ICT terus digunakan oleh para tenaga pendidik maka manfaat pelatihan harus sesuai dengan kebutuhan untuk mengatasi permasalahan seharihari, karena kalau tidak maka ketrampilan teknis yang dimiliki akan mudah terlupakan. Untuk itu seiring dengan peningkatan kompetensi guru/dosen maka lembaga pendiidkan harus memiliki program pemanfaatan ICT yang memaksa beserta aturan reward dan punishment nya. Agar tenaga pendidik mau menggunakan ICT maka perlu didiskripsikan secara jelas dahulu kemanfaatan ICT tersebut secara personal bagi tiap dosen, bukan hanya kemanfaatan bagi lembaga atau pihak lain, karena kalau demikian motivasi dosen untuk mau menggunakan ICT tidak akan kuat.

Dalam rangka menyesuaikan diri dengan kemajuan IPTEK dan era globalisasi, berbagai upaya telah ditempuh pemerintah untuk mengadakan pembaharuan dan peningkatan mutu pendidikan, yang tercermin dalam berbagai kebijakan. Salah satu kebijakan pemerintah antara lain dalam bentuk peningkatan pelayan dengan berbasis manajemen modern, yang tentunya menuntut tenaga pendidik dan lembaga untuk lebih aktif dan kreatif mengadakan penyesuaian.

Dalam menanggapi berbagai kebijakan pemerintah itu, hampir semua lembaga pendidikan merespon secara positif melalui berbagai tindakan, seperti: Melaksanakan kegiatan pelatihan, penataran, seminar dan workshop mengenai ICT. Mengadakan kegiatan pelatihan dan sosialisasi bagi seluruh tenaga pendidk dengan mendatangkan narasumber. Mendorong para tenaga pendidik untuk melanjutkan studinya ke jenjang pendidikan sebagaimana ditentukan pemerintah. Melengkapi berbagai sarana dan media yang dapat menunjang kegiatan pembelajaran. Melaksanakan pembelajaran dengan menggunakan berbagai 
strategi dan metode. Mengadakan studi banding ke dalam dan luar negeri lain yang dipandang lebih maju.

\section{PEMBAHASAN}

Teknologi manajemen adalah input, proses dan output dari sistem. Manajemen ini termasuk menggunakan metode; hardware, software dan pengolahan berarti operasi seperti menghitung, kontrol, pengambilan keputusan, evaluasi dan penyaringan. ICT yang merupakan sistem pembelajaran berbasis multimedia (teknologi yang melibatkan teks, gambar, suara, dan video) mampu membuat penyajian suatu topik bahasan menjadi menarik, tidak monoton dan mudah untuk dicerna. Disamping itu juga dengan digunakannya ICT maka proses pembelajaran tidak terbatas dalam kelas tertutup. Proses pembelajaran dapat dilakukan dimana pun, kapan pun dan oleh siapa pun; tidak terbatas oleh waktu dan ruang.

Dalam setiap kebijakan pemerintah untuk memajukan pendidikan, selalu diikuti kegiatan sosialisasi dan pelatihan. Tetapi berbagai kegiatan tersebut hanya menambah pengetahuan para guru dan kurang mampu merubah cara pemikiran apalagi perilaku di sekolah.

Kegiatan pembelajaran yang dilaksanakan dalam meningkatkan penguasaan ICT adalah meliputi kegiatan pembelajaran secara tatap muka teori dan praktik serta kegiatan field work (dosen/guru memantapkan hasil kegiatan pembelajarannya melalui implementasi langsung sebagai tugas mandiri / kelompok di lapangan atau laboratorium. Dengan maksud untuk memadukan pengalaman wawasan yang diperoleh dari pembelajaran dengan aplikasinya) lembaga pendidikan yang ditunjuk. Pembelajaran meliputi pembelajaran individual dan kelompok yang di dalamnya mempelajari modul dan melaksanakan tugas mandiri yang terstruktur. Setelah mengikuti kegiatan pembelajaran diharapkan nantinya dosen akan dapat mencapai target kompetensi dalam penguasaan ICT.

Hal tersebut juga sejalan dengan hasil penelitian dari Samuel Musungwini, dkk dimana temuannya menunjukkan ada kesenjangan pengetahuan dan bahwa ada perlu melakukan lokakarya untuk mencoba dan mencerahkan dosen pada nilai teknologi ini. Hasil penelitiannya menunjukkan kurangnya pengetahuan sebagai kendala utama untuk adopsi dan penggunaan Google docs (Samuel et al., 2016).

Penguasaan yang baik oleh dosen dan mahasiswa akan dapat meningkatkan efektivitas dan efisiensi proses pembelajaran sehingga hasilnya pun menjadi optimal. Penggunaan teknologi informasi dan komunikasi tidak hanya terbatas pada kegiatan menyampaikan informasi namun juga dapat digunakan untuk menciptakan interaksi belajar. Penggunaan media sosial online digunakan untuk interaksi, diskusi antar siswa, atau siswa dengan guru. Penggunaan e-learning sebagai proses belajar dengan memanfaatkan komputer dan internet juga harus dikembangkan pada guru dan siswa.

Kurang meratanya jangkauan teknologi di wilayah negara Indonesia dapat disiasati diantaranya dengan: (1) Duta daerah tertinggal. Program untuk mengundang duta daerah tertinggal yang terdiri dari perwakilan guru, dosen, siswa maupun mahasiswa dari daerah tersebut untuk mengikuti paket pelatihan pengenalan dan pemanfaatan ICT untuk daerahnya. Dengan adanya duta daerah tertinggal tersebut diharapkan mampu menularkan pengetahuan tentang ICT 
kepada masyarakat di daerahnya tentu hal ini dilakukan pada saat Kenormalan Baru (New Normal) tetap dilaksanakan dengan mengikuti portap pencegahan covid 19. (2) Mencari tahu daerah-daerah yang masih belum menerapkan ICT, dan diharapkan pemerintah membuatkan simple link dalam setiap instansi pendidikan untuk akses informasi bagi masyarakan daerah tersebut. (3) Optimalisasi potensi ICT daerah tertinggal dengan memberdayakan duta daerah tertinggal untuk memberikan ilmunya kepada masyarakat dengan reward berupa fasilitas ICT (duta daerah diberi fasilitas laptop atau garansi internet gratis). Diharapkan dapat menjadi solusi bagi pemerataan kualitas pendidikan di Indonesia dan kesenjangan pendidikan yang dirasakan oleh masyarakat Indonesia yang tinggal di daerah pelosok (tertinggal).

Sedangkan untuk mengatasi kemampuan guru dalam menerapkan ICT maka dapat dilakukan dengan: (1) Mengirim guru untuk mengikuti kegiatan pelatihan, penataran, seminar dan workshop mengenai ICT, (2) Mengadakan kegiatan pelatihan dan sosialisasi bagi seluruh guru dengan mendatangkan narasumber, (3) Mendorong guru untuk melanjutkan studinya ke jenjang pendidikan sebagaimana ditentukan pemerintah, (4) Melengkapi berbagai sarana dan media yang dapat menunjang kegiatan pembelajaran, (5) Melaksanakan pembelajaran dengan menggunakan berbagai strategi dan metode, meskipun tidak semua sekolah mampu melaksanakan secara efektif, dan (6) Mengadakan studi banding ke sekolah lain yang dipandang lebih maju.

Dari hasil penelitian Chris Evans dalam jurnalnya dijelaskan bahwa: (1) secara signifikan lebih banyak siswa berpikir bahwa mempelajari dari podcast lebih cepat dibandingkan dengan mempelajari dari catatan. Ini berarti bahwa mereka mengklaim bahwa mereka belajar lebih banyak dari podcast daripada membaca bagian yang sesuai dari buku teks. Format meringkas dari podcast memiliki manfaat khusus dalam membantu peserta didik fokus pada hal-hal yang penting. (2) Secara signifikan lebih banyak siswa berpikir bahwa podcast lebih efektif daripada buku teks (Adam, 2016). Siswa melaporkan bahwa mereka lebih menerima materi podcast dari materi yang disampaikan dalam bentuk kuliah atau dari buku teks. (3) secara signifikan lebih banyak siswa percaya bahwa mereka lebih mudah menerima materi yang disampaikan melalui podcast dari pada buku pelajaran atau kuliah tradisional. Hal ini menunjukkan bahwa peserta didik merasa lebih terlibat ketika mendengarkan podcast. Melalui memberikan pelajar kontrol yang lebih dari proses belajar, podcast dapat mendorong perkembangan hubungan aktif dengan materi. Sebaliknya, buku pelajaran dan kuliah dapat mendorong hubungan yang pasif dimana peserta didik mengambil peran sederhana penerima informasi. Sampai saat ini, mungkin, peran utama dari kuliah dan buku teks dipandang sebagai memberikan sejumlah besar informasi. Sebaliknya, podcast secara khusus dirancang untuk membantu peserta didik mengasimilasi materi dan membangun pemahaman mereka sendiri. Akhirnya (4) Tidak ada perbedaan signifikan yang ditemukan untuk efektivitas podcast dibandingkan dengan dari catatan atau kemampuan untuk berhubungan dengan dosen saat mendengarkan untuk podcast dibandingkan dengan kuliah tradisional (Evan, 2008). Dengan demikian, podcast memiliki efek yang signifikan dalam meningkatkan pembelajaran mereka. 
Indonesia memiliki wilayah yang cukup luas, namun tidak semua wilayah itu terjangkau oleh teknologi yang memadai. Banyak daerah pelosok yang masih kesulitan untuk menerapkan sistem pendidikan yang layak. Sedangkan di daerah metropolitan pendidikan serta perkembangan ICT sudah begitu luasnya. Percepatan perkembangan ICT di daerah metropolitan ini belum diimbangi oleh perkembangn ICT di daerah pelosok (tertinggal). Pendidikan di daerah ini berjalan ala kadarnya dengan peralatan yang minimal. Akibatnya terjadi berbagai ketimpangan tentang kualitas pendidikan di Indonesia. Berdasarkan pengalaman dari negara-negara yang telah sukses menerapkan ICT untuk mengembangkan pendidikan di negaranya, maka pengalaman tersebut hendaknya menjadi motivasi serta referensi bagi pemerintah. untuk mewujudkan pasal 31 UUD 45: "Setiap warga negara berhak mendapatkan pendidikan yang layak". Kita dapat menggali pengalaman dari negara Thailand (dikutip dari: Belawati, tian., Thailand-ICT Use In Education), rencana nasional Thailand untuk mengintegrasikan sarana dan prasarana dalam pendidikan dan pelatihan pada semua jenjang tidak hanya pada bidang sains dan teknologi namun juga mencakup seluruh aspek. Hal ini memunculkan inisiatif Thailand untuk melakukan beberapa hal berikut: (1) Menyediakan guru, dosen, profesor, siswa dan mahasiswa kesempatan untuk belajar mengimplementasikan ICT. (2) Menciptakan link untuk sekolah, universitas, dan perpustakaan online. (3) Optimalisasi pemanfaatan ICT dan pembelajaran jarak jauh untuk memenuhi kebutuhan akan pembelajaran yang kontinu. Perhatian yang khusus ditujukan bagi masyarakat tertentu yang masih belum familiar dengan ICT (Pima et al., 2016).

Penggunaan ICT dalam system pembelajaran memungkinkan guru maupun siswa untuk memodifikasi program dan siswa dapat meminta yang diinginkan konten yang disajikan dalam sistem. Oleh karenanya harus diperhatikan hal-hal sebagai berikut agar hasil yang diharapkan optimal : Mengubah struktur pendidikan dari terpusat ke terdesentralisasi. Dorongan dan partisipasi sektor swasta dalam pembentukan dan memberikan persyaratan dasar untuk mulai menggunakan teknologi informasi dan komunikasi di pendidikan. Pelatihan manajer, guru, panduan dan kelompok pendidikan dalam kaitannya dengan konten, keterampilan dan penerapan teknologi informasi dan komunikasi harus dilakukan secara efisien.

Meluasnya penggunaan sumber-sumber ilmiah terutama yang penelitian yang telah ilakukan pada informasi dan teknologi komunikasi dan pendekatan yang relevan dipendidikan yang diperlukan. Mempersiapkan keamanan untuk siswa dalam jaringan internet. Efisiensi profesional guru dengan perluasan teknologi informasi dan komunikasi sangat penting. Menggunakan kemampuan internet dalam proses belajar dan mengajar. Menyiapkan keamanan untuk siswa dalam jaringan internet. Meningkatkan pengetahuan orang tua tentang penerapan ICT dalam pendidikan.

\section{SIMPULAN}

Belum meratanya infrastruktur yang mendukung dalam penerapan teknologi dibidang pendidikan dan ketidaksiapan sumber daya manusia untuk memanfaatkan teknologi informasi dan komunikasi dalam proses pembelajaran 


\section{DAFTAR PUSTAKA}

Adam, W. (2016). Student Perception on a Student Response System Formed by Combining Mobile Phone and a Polling Website. International Journal of Education and Development using Information and Communication Technology (IJEDICT), 12(1)

Adisel, A. (2019). Manajemen Sistem Informasi Pembelajaran. ALIGNMENT: Journal of Administration and Educational Management, 2(2), 105-112

Evans, C. (2008). The Effectiveness of M-Learning in the Form of Podcast Revision Lectures in Higher Education (Science Direct, Computer \& Education 50, 2008)

Hashemy, S. A., Hayati, D., \& Hashemy, Z. (2012). A Survey of the Application of Information Communication Technology in Education. International Journal of Information and Education Technology, 2(1)

Pima, J. M., Odetayo, M., Iqbal, R., \& Sedoyeka, E. (2016). Assessing the Available ICT Infrastructure for Collaborative Web Technologies in a Blended Learning Environment in Tanzania: A Mixed Methods Research. International Journal of Education and Development using Information and Communication Technology (IJEDICT), 12(1)

Prawiradilaga, D. S. (2014). Wawasan Teknologi Pendidikan. Jakarta: Kencana Prenada Media Group

Samuel, M., Mugoniwa, B., Furusa, S. S., \& Rebanowako, T. G. (2016). An Analysis of the Use of Cloud Computing among University Lecturers:

A Case Study in Zimbabwe. International Journal of Education and Development using Information and Communication Technology (IJEDICT), 12(1)

Unesco. (2011). Education for All Global Monitoring Report. http://www.edukasi.kompas.com/read/2011/03/04463810/peringka.pendidik an.indonesia.turun/

William, W. S., Forsman, A., \& Yan, J. (2015). An E-Curriculum Based Systematic Resource Integration Approach to Web-Based Education. International Journal of Information and Education Technology, 5(7) 